\title{
Meniscus, a New Genus of Aerotolerant, Gas-Vacuolated Bacteria
}

\author{
ROAR L. IRGENS \\ Department of Life Sciences, Southwest Missouri State University, Springfield, Missouri 65802
}

\begin{abstract}
Two gram-negative, gas-vacuolated, aerotolerant, heterotrophic bacteria were isolated from the anaerobic digester of the Göttingen Waste Treatment Plant, Göttingen, Federal Republic of Germany. Pure white colonies of these organisms were picked from pour plates of basal growth medium containing $1.2 \%$ agar. The plates had been inoculated with digester sludge and incubated in a nitrogen-carbon dioxide atmosphere using the agar itself as the main carbon and energy source. One organism was rod shaped, and the other was vibrioid; both were encapsulated and nonmotile. The two organisms have identical deoxyribonucleic acid base compositions and identical nutritional requirements and fermentation characteristics. It is proposed that these organisms are stable morphovaric forms of a single species belonging to a new genus, for which the name Meniscus is proposed. The name proposed for the species (the type species) is Meniscus glaucopis sp. nov., of which the type strain is strain V (= ATCC 29398). The genus Meniscus does not appear to belong to any of the currently recognized families of bacteria.
\end{abstract}

Gas vesicles are found primarily in procaryotic organisms from aquatic habitats. They are particularly common in phototrophic organisms such as the blue-green bacteria and the green and purple sulfur bacteria (4), but they have also been reported in a number of heterotrophic bacteria (9-11). Although bacteria containing gas vesicles have been demonstrated in the hypolimnetic layer of some lakes $(2,5,12)$, successful cultivation of these hypolimnetic heterotrophs in the laboratory has not been reported in the literature.

The colonies of the organisms reported here were first observed on agar pour plates designed for the counting of phototrophs. The medium had been inoculated with sludge from the anaerobic digester of the Göttingen Waste Treatment Plant, Göttingen, Federal Republic of Germany. The organisms were recognized as being unusual, and it was decided to attempt their isolation and classification.

\section{MATERIALS AND METHODS}

Bacterial strains. The organisms were isolated from anaerobic digester sludge collected in sterile jars at the Göttingen Waste Treatment Plant, Göttingen, Federal Republic of Germany. The samples were diluted $10^{-1}, 10^{-2}, 10^{-3}$, and $10^{-4}$ with sterile distilled water. One milliliter of each dilution was added to $100 \mathrm{ml}$ of maltose-free basal growth medium (BGM) plus $1.2 \%$ agar kept at $40^{\circ} \mathrm{C}$, and the agar was poured into four petri dishes. After 2 weeks of anaerobic incubation at $30^{\circ} \mathrm{C}$, chalky white colonies were observed on the plates. The agar under and surrounding the colonies was soft due to hydrolysis of the agar. The plates prepared from the $10^{-1}$ dilution contained about 200 colonies each. Phasemicroscopy examination revealed that some colonies consisted of rods whereas others consisted of vibrios. Most of the cells contained bright, refractile regions thought to be gas vacuoles. Each colony type was purified by streaking on BGM agar plus $0.5 \%$ maltose. The strains were designated "R" for rod and "V" for vibrio.

Cultures were maintained at $4^{\circ} \mathrm{C}$ in BGM deeps containing $0.3 \%$ agar, $0.2 \%$ maltose, and $1.0 \%$ $\mathrm{CaCO}_{3}$. The tubes were rendered anaerobic by means of cotton plugs containing $0.5 \mathrm{ml}$ of concentrated $\mathrm{Na}_{2} \mathrm{CO}_{3}$ and $0.5 \mathrm{ml}$ of $20 \%$ pyrogallic acid. They were then sealed with rubber stoppers (8). The two organisms were run in parallel in all experiments. The vibrioid strain was deposited with the American Type Culture Collection (ATCC), Rockville, Md., under the number 29398.

Media. BGM contained (per liter): yeast extract, $1.0 \mathrm{~g} ; \mathrm{KH}_{2} \mathrm{PO}_{4}, 0.5 \mathrm{~g} ; \mathrm{NaCl}, 0.4 \mathrm{~g} ; \mathrm{NH}_{4} \mathrm{Cl}, 0.4 \mathrm{~g}$; $\mathrm{CaCl}_{2} \cdot 2 \mathrm{H}_{2} \mathrm{O}, 0.01 \mathrm{~g}$; sodium thioglycolate, $0.3 \mathrm{~g}$; $\mathrm{MgSO}_{4} \cdot 7 \mathrm{H}_{2} \mathrm{O}, 0.2 \mathrm{~g} ; \mathrm{FeSO}_{4} \cdot 7 \mathrm{H}_{2} \mathrm{O}, 0.001 \mathrm{~g}$; trace elements solution (TES), $1.0 \mathrm{ml}$. The TES, modified from Pfennig's formula (personal communication), contained (per liter): $\mathrm{ZnSO}_{4} \cdot 7 \mathrm{H}_{2} \mathrm{O}, 0.10 \mathrm{~g}$; $\mathrm{MnCl}$ $4 \mathrm{H}_{2} \mathrm{O}, 0.03 \mathrm{~g} ; \mathrm{H}_{3} \mathrm{BO}_{3}, 0.3 \mathrm{~g} ; \mathrm{CoCl}_{2} \cdot 6 \mathrm{H}_{2} \mathrm{O}, 0.2 \mathrm{~g}$; $\mathrm{CuCl}_{2} \cdot 2 \mathrm{H}_{2} \mathrm{O}, 0.01 \mathrm{~g} ; \mathrm{NiCl}_{2} \cdot 6 \mathrm{H}_{2} \mathrm{O}, 0.02 \mathrm{~g} ; \mathrm{Na}_{2} \mathrm{MoO}_{4} \cdot$ $2 \mathrm{H}_{2} \mathrm{O}, 0.03 \mathrm{~g} ; \mathrm{pH} 3$ to 4 .

The $\mathrm{pH}$ of the BGM was adjusted to 7.3 with $10 \%$ $\mathrm{Na}_{2} \mathrm{CO}_{3}$ before autoclaving, or the medium was autoclaved with the $\mathrm{pH}$ unadjusted and then adjusted to about $\mathrm{pH} 7.0$ after autoclaving by the addition of $2.0 \mathrm{ml}$ of filter-sterilized $5.0 \% \mathrm{NaHCO}_{3}$ per $100 \mathrm{ml}$ of BGM. All solid media contained $1.0 \% \mathrm{CaCO}_{3}$ and $1.5 \%$ agar. Stock medium contained $0.3 \%$ agar. Mal- 
tose, at a concentration of 0.2 to $0.5 \%$, was, in general, used as the carbon source. Large volumes of liquid cultures were sparged with $\mathrm{N}_{2}$ gas for $15 \mathrm{~min}$ prior to and after inoculation. Smaller volumes in test tubes were rendered anaerobic by means of $20 \%$ pyrogallic acid and concentrated $\mathrm{Na}_{2} \mathrm{CO}_{3}(8)$ or by the use of Hungate tubes sparged with $\mathrm{N}_{2}$ gas prior to autoclaving. Resazurin, at a concentration of 0.1 $\mathrm{mg} / 100 \mathrm{ml}$, was used as an oxidation-reduction indicator. Agar plate cultures were grown in anaerobic jars (BBL) or in glass jars filled with $20 \% \mathrm{CO}_{2}$ and $80 \% \mathrm{H}_{2}$ or $\mathrm{N}_{2}$ gas.

Techniques of microscopic observation. Phase photomicrographs were taken on 35-mm high-contrast copy film (Kodak) with a Cannon FTB camera attached to a Zeiss RA38 microscope. The presence of gas vacuoles was demonstrated by the disappearance of the vacuoles upon the application of a sharp blow with a hammer to a wet mount of the cells. The cover slip was protected with a 3- to 4-mm-thick rubber pad. Phase-microscopic examination of wet mounts made with dilute India ink was used to demonstrate capsules.

A Hitachi HU-11E electron microscope was used for observation of sectioned cells. Concentrated suspensions of bacteria from agar plates were fixed at $4^{\circ} \mathrm{C}$ for $30 \mathrm{~min}$ in large volumes of phosphatebuffered (pH 6.8) glutaraldehyde (2.5\%). These suspensions were mixed with equal volumes of warm $4 \%$ agar and then cut into 1-mm cubes. The agarembedded bacteria were postfixed at $4^{\circ} \mathrm{C}$ in phosphate-buffered ( $\mathrm{pH}$ 6.8) $\mathrm{OsO}_{4}(1 \%)$ for $1 \mathrm{~h}$. The blocks were dehydrated in alcohol and embedded in Araldite 502. Thin sections were stained with uranyl acetate and lead citrate.

Methods of bacteriological characterization. Unless otherwise specified, all inocula used in specified tests were taken from young cultures grown on BGM agar plates plus $0.5 \%$ maltose and suspended in BGM without yeast extract. All test cultures were incubated for 7 to 30 days at $30^{\circ} \mathrm{C}$ and examined with a microscope for contamination before a particular test was confirmed. All tests were run in duplicate. BGM plus $0.2 \%$ maltose and without yeast extract was used for the determination of vitamin requirements. All glassware for this determination was acid cleaned. Forty-five carbon sources were tested for utilization at a concentration of $0.2 \%(\mathrm{wt} / \mathrm{vol})$. Growth at various temperatures was determined by using BGM agar plus $0.5 \%$ maltose. Incubation at 5 , $10,15,20,25,30,35$, and $40^{\circ} \mathrm{C}$ was extended for 30 days.

The initial $\mathrm{pH}$ for growth was determined by adjusting the $\mathrm{pH}$ of BGM agar plus $0.5 \%$ maltose with dilute $\mathrm{HCl}$ or $\mathrm{NaOH}$ prior to inoculation. This value was recorded as the growth $\mathrm{pH}$. Aerobic growth was tested on BGM agar plates plus $0.5 \%$ maltose. Macromolecular hydrolysis was tested on BGM agar containing $0.5 \%$ maltose plus the proper ingredient or in test tubes with the agar and the maltose left out. The following were tested on plates: starch, $0.5 \%$; tributyrin, $1.0 \%$; cellulose, $0.3 \%$; xylan, $0.3 \%$; chitin (6), 1.0\%; deoxyribonucleic acid (DNA), $0.2 \%$; and casein, $0.5 \%$. Hydrolysis of these compounds was indicated by the formation of a clear zone around the colony. Starch and DNA hydrolyses were demonstrated with the aid of Lugol iodine and 1-N $\mathrm{HCl}$, respectively. Tested in tubes were the following: glycogen, $0.5 \%$; inulin, $0.2 \%$; pectin, $0.3 \%$; gum arabic, $0.2 \%$; and dextrin, $0.2 \%$. Since BGM alone does not support growth of these organisms, hydrolysis was indicated by growth (turbidity) and acid production (drop in $\mathrm{pH}$ ). A test for hydrolysis of agar, $0.3 \%$, and gelatin, $5.0 \%$, was done in test tubes. Hydrolysis was demonstrated by the inability of the culture medium to solidify when immersed in ice water after incubation.

Catalase and oxidase were tested for by dropping $3.0 \% \mathrm{H}_{2} \mathrm{O}_{2}$ and $1.0 \%$ p-amino dimethylaniline oxalate, respectively, onto colonies on BGM agar plus $0.5 \%$ maltose. Deaminase and urease were tested for by growing the cells in media containing Casamino Acids and urea, respectively. Production of ammonia was checked with Nessler reagent. The test for acetylmethylcarbinol (AMC) production was performed by adding $40 \% \mathrm{KOH}$ containing $0.3 \%$ creatine and $5 \%$ alpha-naphthol (in $95 \%$ ethanol) to a maltose-grown culture.

Nitrate reduction was tested in BGM containing $0.2 \%$ maltose and $0.5 \% \mathrm{KNO}_{3}$. The formation of nitrate was checked by the addition of sulfanilic acid $(8.0 \mathrm{~g}$ in $1,000 \mathrm{ml}$ of $5.0 \mathrm{~N}$ acetic acid) and dimethylalpha-naphthylamine $(5.0 \mathrm{~g}$ in $1,000 \mathrm{ml}$ of $5.0 \mathrm{~N}$ acetic acid).

Indole production was determined by growing the cells in $\mathrm{BGM}+0.05 \%$ maltose and $0.5 \%$ tryptophan and by adding Kovac reagent $(5.0 \mathrm{~g}$ of $p$-dimethylaminobenzaldehyde in $75 \mathrm{ml}$ of amyl alcohol and 25 $\mathrm{ml}$ of concentrated $\mathrm{HCl}$ ) to the grown culture. The production of $\mathrm{H}_{2} \mathrm{~S}$ was tested for in SIM medium (Difco) plus $0.1 \%$ yeast extract and vitamin $\mathrm{B}_{12}$.

DNA was extracted by the procedure of Marmur (7), and its mean base composition (moles percent guanine plus cytosine $[\mathrm{G}+\mathrm{C}]$ ) was determined by Mandel using the buoyant density $\mathrm{CsCl}$ method (7).

\section{RESULTS}

Morphological characteristics. Figures 1 and 2 show phase-contrast photomicrographs of strains " $R$ " and "V," respectively. The rods measured approximately 0.7 by $2.0 \mu \mathrm{m}$, and the vibrios were about $0.7 \mu \mathrm{m}$ wide with an outer diameter of $3.0 \mu \mathrm{m}$. Both organisms were encapsulated, gram negative, and nonmotile.

The cells of both strains contained bright, refractile regions of irregular outline. Figure 3 shows an electron micrograph of the rods. The individual vesicles of the gas vacuole were clearly visible.

Cultural characteristics. On agar plates, both strains produced colonies with a circular form, an entire margin, convex elevation, and a smooth, glistening surface. The colonies appeared translucent or opaque, chalky white. As previously found by Van Ert and Staley (10), the variation in colony opacity is apparently due to variation in the number of gas vacuoles 


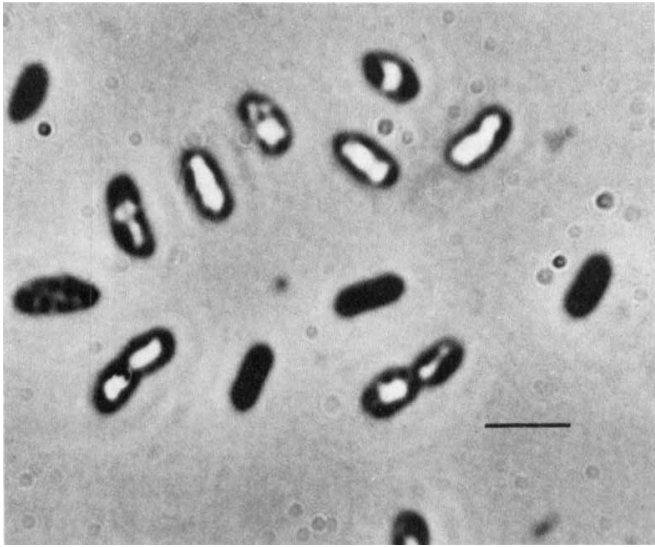

FIG. 1. Phase photomicrograph of strain $R$, the rod-shaped isolate. Note the refractile appearance of the gas vacuoles. Marker indicates $2 \mu \mathrm{m}$.

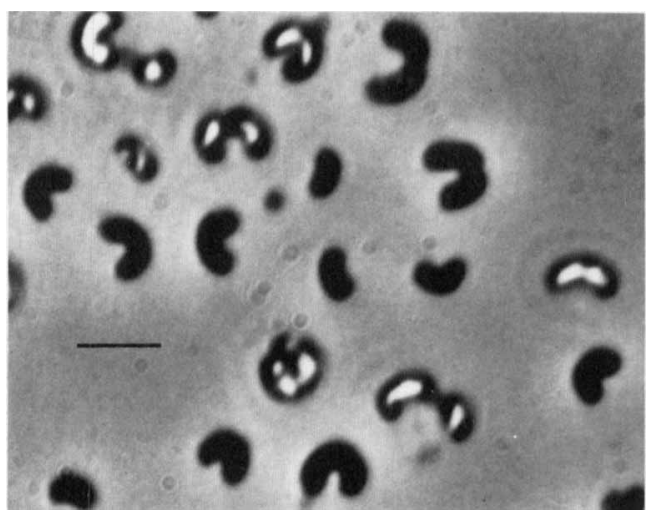

FIg. 2. Phase photomicrograph of strain V, the vibrioid isolate. Note the refractile appearance of the gas vacuoles. Marker indicates $2 \mu \mathrm{m}$.

within the individual cells of the colony. The translucent colonies contained fewer cells with gas vacuoles. In agar shakes, the colonies were compound lenticular (Y shaped). Cells of both organisms grew evenly suspended in anaerobic liquid media on a magnetic stirring base. In stationary cultures, the cells remained fairly evenly suspended or collected at the surface. Refrigeration especially enhanced the tendency of the cells to collect at the surface. This was mainly due to the increased density of water at $4^{\circ} \mathrm{C}$. At no time was the formation of pellicles observed.

Growth characteristics. Both strains grew in the 15 to $35^{\circ} \mathrm{C}$ range. They did not grow at 10 and $40^{\circ} \mathrm{C}$. The optimum $\mathrm{pH}$ for growth of both organisms was between 7.0 and 8.0. There was little growth of either organsim below $\mathrm{pH} 6.0$ or above $\mathrm{pH} 10.0$.

Both strains grew under aerobic conditions on BGM agar plus $0.5 \%$ maltose provided the concentration of $\mathrm{CO}_{2}$ was at least $1 \%$. They also grew in a candle jar. It was noted that the colonies of cultures grown under aerobic conditions stuck to the agar and had a rubbery consistency, whereas the cultures grown under anaerobic conditions had a buttery consistency. Both strains tested negative for catalase, oxidase, deaminase, urease, acetylmethylcarbinol, indole, $\mathrm{H}_{2} \mathrm{~S}$, and nitrate reduction.

Nutrition. Both organisms grew well on BGM plus maltose. Thiamin, cobalamine (vi$\operatorname{tamin} \mathrm{B}_{12}$ ), and $\mathrm{CO}_{2}$ were required for growth. There also appeared to be a need for ammonium ion or yeast extract. Both organisms grew in BGM plus maltose when yeast extract was replaced with a vitamin mixture (B vitamins plus biotin and nicotinic acid) or when $\mathrm{NH}_{4} \mathrm{Cl}$ was replaced with vitamin-free Casamino Acids. However, neither organism grew when both the yeast extract and the $\mathrm{NH}_{4} \mathrm{Cl}$ were replaced with vitamin mixture and Casamino Acids. These results can be explained by the inability of either strain to carry out deamination, ammonia being required for the synthesis of purines and pyrmidines. The latter compounds are provided in media by the yeast extract.

Both organisms showed identical responses to 45 carbon sources tested for the ability to serve as carbon and energy sources for growth. Both organisms fermented melezitose, raffinose, cellobiose, sucrose, lactose, maltose, melibiose, trehalose, fructose, galactose, glucose, rhamnose, $\mathrm{CH}_{3}$-alpha-D-glucoside, esculin, salicin, D-ribose, D-xylose, and D-arabinose. They did not ferment mannose, sorbose, glycerol, mannitol, sorbitol, adonitol, dulcitol, inositol, or amino acids.

Neither organism could hydrolyze starch, cellulose, DNA, gelatin, casein, pectin, inulin, gum arabic, tributyrin, chitin, xylan, or glycogen. Both organsims were able to hydrolyze agar and dextrin. End products formed from the fermentation of glucose were acetic, propionic, and succinic acids.

The $\mathrm{G}+\mathrm{C}$ content of the DNA for both organisms was $44.9 \mathrm{~mol} \%$.

\section{DISCUSSION}

Nutrition. Strains "R" and "V" responded identically to the organic substrates tested. Both had a fermentative metabolism and utilized the same substrates. Large amounts of acid but no gas were formed. Their vitamin re- 


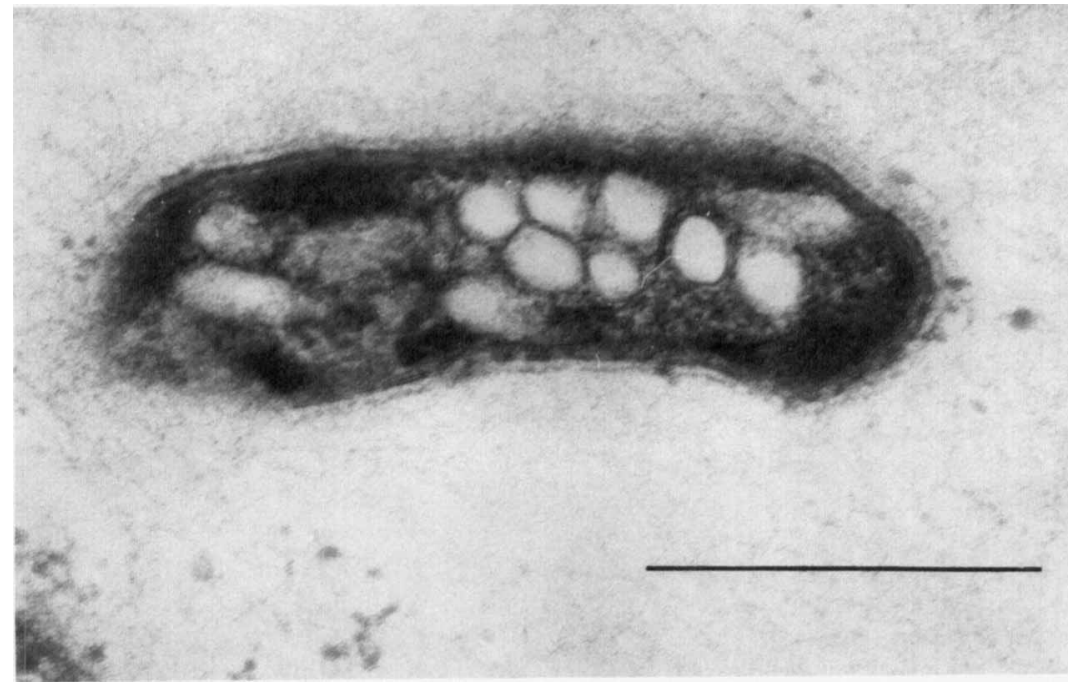

FIG. 3. Electron micrograph of a longitudinal section of the rod-shaped cell resolving the fine struct.ure of the vesicles comprising the gas vacuoles. The diameter of the vesicles measures approximately $100 \mathrm{~nm}$. Marker indicates $1.0 \mu \mathrm{m}$.

quirements and their DNA base compositions also were identical.

Morphological characteristics. Both strains were nonmotile, encapsulated, and aerotolerant. Strain "R" contained rod-shaped cells which measured 0.7 by $2.0 \mu \mathrm{m}$. The cells occurred mostly singly, but some pairs and chains of cells could be observed. Strain "V" contained vibrioid cells about 0.7 to $1.0 \mu \mathrm{m}$ thick and often gave the appearance of forming rings due to the overlapping ends. The outer "ring" diameter was about $3.0 \mu \mathrm{m}$. Under certain undefined conditions, long, tightly coiled spirals, $S$ shapes, and pretzel shapes could be observed.

For the purpose of classification, it would be of interest to compare the two new isolates to other heterotrophs that form gas vacuoles. One may mention the genera Halobacterium (1), Anacalomicrobium (1, 9), Prosthecomicrobium $(1,9)$, and Microcyclus $(1,3,10)$, the members of which have been cultivated, and Pelonema (1), Peloploca (1), Pelosigma (1), and Brachyarcus (1), the members of which have not been cultivated.

The two new isolates do not fit the description of the first four genera mentioned above for the following reasons: both species of the genus Halobacterium are obligately aerobic halophiles with a $\mathrm{G}+\mathrm{C}$ content of the major DNA component of 66 to $68 \mathrm{~mol} \%$. Ancalomicrobium and Prosthecomicrobium are both prosthecate bacteria. Ancalomicrobium contains one species, a facultative anaerobe with a DNA G+C content of $70.4 \mathrm{~mol} \%$. The species of the genus
Prosthecomicrobium are strict aerobes and have a DNA G+C content of 65.8 to $69.9 \mathrm{~mol} \%$. Microcyclus is not a well-defined genus, and the $\mathrm{G}+\mathrm{C}$ content of the DNA ranges from 39.5 to $68.4 \mathrm{~mol} \%$. The $\mathrm{G}+\mathrm{C}$ contents of the new isolates fit within this range. However, the three species of Microcyclus are all catalase positive, strict aerobes, whereas the new isolates are catalase-negative, aerotolerant anaerobes with a $\mathrm{CO}_{2}$ requirement.

Since members of Pelonema, Peloploca, Pelosigma, and Brachyarcus have not been isolated and cultivated in pure culture, a comparison of the new isolates with these organisms must of necessity be limited to morphological characteristics. Pelonema and Peloploca species all form long multicellular filaments, up to $600 \mu \mathrm{m}$ long, and propagation is by fragmentation of the filaments. These characteristics have not been observed in the new isolates. The two Pelosigma species have been observed to form sigmoid aggregates of four cells and multiples of four cells. This characteristic also has not been observed in the new isolates. The vibrioid isolate has many characteristics in common with the genus Brachyarcus, first described by Skuja (1) in 1964. Both organisms are bent like a bow, are colorless with gas vacuoles, and have encapsulated cells. However, whereas Brachyarcus thiophilus, the type species of Brachyarcus, has occasionally been observed to accumulate minute sulfur granules (1), the new isolates have not been observed to form sulfur granules, even when grown with small 
amounts of $\mathrm{H}_{2} \mathrm{~S}$ in the atmosphere.

It is evident from the discussion above that the mere presence of gas vacuoles in cells cannot serve as a unifying taxonomic characteristic. One must, therefore, consider the possible relationship of the new isolates to nonvacuolated vibrioid organisms, the most likely families being the Spirillaceae and the Vibrionaceae. As the members of Spirillaceae are oxidase positive and incapable of fermenting carbohydrates, the new isolates must be excluded from this family. Although members of the family Vibrionaceae are facultative anaerobes, they are also oxidase and catalase positive, and they carry out respiration in the presence of oxygen. These characteristics eliminate the new isolates from membership in this family. The new isolates do not carry out respiration in the presence of oxygen, as indicated by the same amount of growth being obtained under both aerobic and anaerobic conditions. Because the difference in morphology is the only apparent difference between the new isolates, it is proposed that these organisms are merely morphovars (morphotypes) of the same species. It is further proposed that this organism be placed in a new genus, Meniscus (Gr. n. meniskos crescent moon), and that the species be named $M$. glaucopis sp. nov. (Gr. adj. glaukopis gleaming eyed).

Meniscus gen. nov. Curved or straight rods, 0.7 to 1.0 by 2.0 to $3.0 \mu \mathrm{m}$. Nonmotile. Resting stages not known. Encapsulated. Gas vacuoles arranged at random within the cells. Gram negative. Colonies chalky white. Chemoorganotrophic; fermentative metabolism with no gas production. Facultatively anaerobic with a $\mathrm{CO}_{2}$ requirement. Vitamins $\mathrm{B}_{12}$ and thiamin are required for growth. Temperature for optimum growth: $30^{\circ} \mathrm{C}$; no growth at 10 or at $40^{\circ} \mathrm{C}$. The $\mathrm{G}+\mathrm{C}$ content of the DNA is $44.9 \mathrm{~mol} \%$. The type species is $M$. glaucopis sp. nov.

Meniscus glaucopis sp. nov. Unicellular, gram negative, vibrioid or rod-shaped cells, 0.7 to 1.0 by 2.0 to $3.0 \mu \mathrm{m}$, colorless with gas vacuoles. Cultures may show single cells, pairs, tightly coiled spirals, $\mathrm{S}$ shapes (two cells, one inverted), and doughnut-shaped cells, where the ends are overlapping before division by binary fission has occurred. The cells are encapsulated. No resting stages known.

Colonies are circular, convex in elevation, with an entire margin and smooth, glistening surface. The colonies may appear translucent or opaque, chalky white. The larger the number of gas vacuoles within the cells of the colony, the whiter the colony. The consistency of the colonies is buttery when grown anaerobically and rubbery when grown aerobically.
Aerotolerant anaerobic with a $\mathrm{CO}_{2}$ requirement. Catalase and oxidase negative. Does not carry out respiration. Nitrate not reduced. Optimum growth occurs around $30^{\circ} \mathrm{C}$ at $\mathrm{pH}$ 7.0. Growth occurs at 15 and $35^{\circ} \mathrm{C}$, but not at 10 or $40^{\circ} \mathrm{C}$. Cobalamine (vitamin $\mathrm{B}_{12}$ ), thiamin, and $\mathrm{CO}_{2}$ are required for growth. Good growth in defined medium occurs with ammonium as the nitrogen source.

The following characteristics were negative: deaminase, urease, acetylmethylcarbinol, indole, and $\mathrm{H}_{2} \mathrm{~S}$ production and nitrate reduction.

Ferments agar, dextrin, melezitose, raffinose, cellobiose, sucrose, lactose, maltose, melibiose, trehalose, fructose, galactose, glucose, rhamnose (weakly), $\mathrm{CH}_{3}$-alpha-D-glucoside, esculin, salicin, D-ribose, D-xylose, and arabinose.

Does not ferment mannose, sorbose, glycerol, lactate, mannitol, sorbitol, adonitol, dulcitol, inositol, or amino acids.

Does not hydrolyze starch, cellulose, DNA, gelatin, casein, pectin, inulin, gum arabic, tributyrin, chitin, xylan, or glycogen.

Fermentation end products are acetic, propionic, and succinic acids.

The $\mathrm{G}+\mathrm{C}$ content of the DNA is $44.9 \mathrm{~mol} \%$.

Isloated from anaerobic digester sludge, but probably also present in anaerobic hypolimnion of lakes.

Type strain: strain V (= ATCC 29398).

\section{ACKNOWLEDGMENTS}

I thank Norbert Pfenning for providing laboratory space during the initial isolation of the organisms, M. Mandel for determining the DNA base compositions, W. E. C. Moore of the VPI Anaerobe Laboratory, Blacksburg, Va., for his help in determining the fermentation end products, and Marilyn Fitzner for the electron microscope work

This work was supported by a research grant from the faculty research committee, Southwest Missouri State University.

\section{REPRINT REQUESTS}

Address reprint requests to: Dr. Roar L. Irgens, Dept. of Life Sciences, Southwest Missouri State Univ., Springfield, MO 65802 .

\section{LITERATURE CITED}

1. Buchanan, R. E., and N. E. Gibbons (ed.). 1974. Bergey's manual of determinative bacteriology, 8th ed. The Williams and Wilkins Co., Baltimore.

2. Caldwell, D. E., and J. M. Tiedje. 1975. A morphological study of anaerobic bacteria from the hypolimnia of two Michigan Lakes. Can. J. Microbiol. 21:362-376.

3. Claus, D., J. E. Bergendahl, and M. Mandel. 1968. DNA base composition of Microcyclus species and organisms of similar morphology. Arch Mikrobiol. 63:26-28.

4. Cohen-Bazire, G., R. Kunisawa, and N. Pfennig. 1969 Comparative study of the structure of gas vacuoles. $J$ Bacteriol. 100:1049-1061.

5. Hirsch, P., and S. H. Pankratz. 1970. Study of bacterial populations in natural environments by use of sub- 
merged electron microscope grids. Z. Allg. Mikrobiol. 10:589-605.

6. Hsu, S. C., and J. L. Lockwood. 1975. Powdered chitin agar as a selective medium for enumeration of Actinomycetes in water and soil. Appl. Microbiol. 29:422426.

7. Marmur, J. 1961. A procedure for the isolation of deoxy. ribonucleic acid from microorganisms. J. Mol. Biol. $3: 208-218$.

8. Seeley, H. W., Jr., and P. J. Vandermark. 1972. Microbes in action, 2nd ed., p. 71. W. H. Freeman and Co., San Francisco.
9. Staley, J. T. 1968. Prosthecomicrobium and Ancalomicrobium: new prosthecate freshwater bacteria. J. Bacteriol. 95:1921-1942.

10. Van Ert, M., and J. T. Staley. 1971. Gas-vacuolated strains of Microcyclus aquaticus. J. Bacteriol. 108:236-240.

11. Van Ert, M., and J. T. Staley. 1971. A new gas vacuolated heterotrophic rod from freshwaters. Arch. Mikrobiol. 80:70-77.

12. Walsby, A. E. 1974. The identification of gas vacuoles and their abundance in the hypolimnetic bacteria of Arco Lake, Minnesota. Microbiol. Ecol. 1:51-61. 